\title{
Another Look at Job and Life Satisfaction among Employees: Evidence from a Developing Country
}

\author{
Faris S. Alghamdi \\ Faculty of Financial and Administrative Sciences, Albaha University, Albaha, KSA \\ Email: fsaleh@bu.edu.sa \\ Received 3 December 2014; revised 28 December 2014; accepted 18 January 2015 \\ Copyright (C) 2015 by author and Scientific Research Publishing Inc. \\ This work is licensed under the Creative Commons Attribution International License (CC BY). \\ http://creativecommons.org/licenses/by/4.0/

(c) (i) Open Access

\begin{abstract}
Organizational literature has demonstrated remarkable attention to the relationship between job and life satisfaction. Approaching the relationship between job and life satisfaction from an attitudinal perspective, the present study was conducted to examine the relationship between job and life satisfaction in Southern Saudi Arabia. It also aimed to investigate the contribution of demographic and socioeconomic variables in predicting job and life satisfaction. The results of Pearson correlation analysis and hierarchical regression analysis revealed a statistically significant relationship between job and life satisfaction, even after controlling for demographic and socioeconomic variables. The results also suggested that job satisfaction and life satisfaction were positively and reciprocally related. Having controlled for demographic and socioeconomic variables, the age variable was uniquely predicted job satisfaction. Additionally, Tukey's post-hoc test showed that participants whose age ranged from 40 to 50 were more satisfied with their jobs $(M=3.73$; SD $=0.35$ ) than those from 18 to 28 and from 29 to 39 . That is, older employees were more satisfied with their jobs than younger employees.
\end{abstract}

\section{Keywords}

Job Satisfaction, Life Satisfaction, Employees, Developing Country

\section{Introduction}

In recent times, job satisfaction and life satisfaction have been preeminently studied by researchers interested in such topic, especially those in the field of organizational behavior. Employees with high levels of job satisfaction and life satisfaction are likely to be highly motivated, and to work more effective and efficient, resulting in 
high levels of job performance [1]-[3]. Job satisfaction is a central construct in organizational behavior and therefore associated with important outcomes including, but not limited to, productivity, job performance, organizational citizenship behaviors, absenteeism, and life satisfaction. It can directly influence social, physical, and mental health of organizational members [4] [5].

Generally, the concept of job satisfaction was understood only in 1930s and 1940s and hence began to be a topic of interest in several sub-disciplines of social sciences. Even though job satisfaction has been a topic of interest to researchers for years, it is still a key factor in modern management mentality [5]. The concept of job satisfaction has been defined in many ways. However, [6] claimed that the most widely used definition in organizational research was that of Locke [7], who described job satisfaction as "a pleasure or positive emotional state resulting from the appraisal of one's job or job experiences” (p. 1304).

[8] claimed that three separable components of subjective well-being have been identified: positive affect, negative affect, and life satisfaction. The former two components refer to the affective, emotional aspects of the construct, whereas the latter refers to the cognitive-judgmental aspects. Life elapses and individuals have different expectations, needs, desires, and priorities, to name a few. [9] defined life satisfaction as "a global assessment of a person's quality of life according to his chosen criteria" (p. 478). It should be noted that the judgment of satisfaction is dependent on a comparison of one's circumstances with what is assumed to be a proper standard. Having said that, the judgment of how satisfied individuals are with their current state of affairs is based upon a comparison with a standard, whereby each individual sets for himself or herself. Most importantly, it concentrates on the person's own judgments, not on some criterions judged to be important by the investigator. As such, researchers need to ask the individuals for their overall evaluation of their life, instead of summing across their satisfaction with particular domains [8] [10] [11] pointing out that “...happiness requires total satisfaction that is satisfaction with life as a whole” (p. 8).

\section{Relationship between Job and Life Satisfaction}

The relationship between job and life satisfaction was initially investigated by [12]. This relationship has received substantial attention in the organizational research [4] [13] [14]. As a result, three traditional paradigms have been put forth to explain the relationship between job and life satisfaction, namely the spillover model, the compensatory model, and the segmentation model. Conceptualization of the overlap between job and life satisfaction [15] was initially planned to mirror activities instead of emotions or attitudes. This study will approach the relationship between job and life satisfaction from an attitudinal perspective.

From an attitudinal perspective, the spillover model indicates that one domain spills over onto other such that employees who are dissatisfied with their jobs will be dissatisfied with their lives, and vice versa, suggesting a positive relationship exists between the two variables. The compensatory model proposes that employees who are dissatisfied with their jobs seek out more pleasurable experiences in their non-work lives, and vice versa, suggesting a negative relationship exists between the two variables. Finally, the segmentation model assumes that there is no relationship between job and life satisfaction. They are independent of one another, suggesting a weak or non-significant relationship between the two variables [3] [4] [16]. Moreover, there are two fundamentally different models that can be used to interpret the relationship between job and life satisfaction: the bottom-up model and top-down model. The former is a situational explanation, assuming that since the job is an important part of adult daily life, employees who enjoy their jobs will report greater overall satisfaction with their lives. On the other hand, the latter is a dispositional explanation, suggesting that basic differences in personality and affectivity incline people to be differentially satisfied with various aspects of their lives, their jobs included [10] [17].

A number of studies have been conducted to examine the relationship between job and life satisfaction. Most contemporary research inclines to support the spillover model (e.g., [3] [4] [16] [18]-[22]). Unfortunately, to the best of my knowledge, there is scant attention, if not, has been paid to examine the relationship between job and life satisfaction in Saudi Arabia, particularly Albaha province, and hence the current study was planned to be made.

Based upon the foregoing discussion, the current study was designed to address two main research questions:

1. Are job and life satisfaction significantly positively related while controlling for demographic and socioeconomic variables?

2. What is the relative contribution of demographic and socioeconomic variables in predicting job and life satisfaction? 


\section{Methodology}

\subsection{Sample}

The target population for this study consists of all male and female employees in different organizations Albaha province, Saudi Arabia. The participants included in this study must meet the three main criteria: 1) full-time employees, 2) working for pay at least 30 hours per week, and 3) at the age of 18 years or above. Self-employed individuals were not included. In maintaining confidentiality for all participants, the informed consent was obtained from all participants before the process of collecting the data; and the anonymity of all participants was preserved as well. A cover letter providing some information about the importance of the study, participants' rights, as well as explaining how to respond to the questionnaire items was attached. The sample of the study was selected using the convenience sampling technique. The questionnaire includes three parts: demographic and socioeconomic information, life satisfaction scale, and job satisfaction scale. There were 186 questionnaires distributed to participants who met the criteria mentioned above. Trained employees worked with the researcher have been assigned to distribute the questionnaires to potential subjects and then collect all questionnaires that have been filled out. Of distributed questionnaires, 153 were returned and useful for carrying out the study analysis, with response rate of $82 \%$.

\subsection{Instrument}

The current study applied a descriptive cross-sectional method, using the 5-item satisfaction with life scale SWLS; [8] to assess overall life satisfaction. This scale has been one of the most widely used scales for the measurement of the construct. Research has established acceptable psychometric properties for the scale, including high internal consistency, test-retest reliability, and convergent validity [23]-[26]. This instrument has been applied and validated in several different cultural settings with different socio-demographic groups of individuals [27]-[30]. Next, this study measures overall job satisfaction with five items, 4-item of which were taken from the Brayfield-Rothe's job satisfaction scale [31], and 1-itme was taken from the Mak and Sockel's job satisfaction scale [32]. One item (Brayfield-Rothe, 1951) stated "I consider my job rather unpleasant" is reverse scored that addressed before computing the scores on the instrument. It should be noted that Brayfield-Rothe's (1951) job satisfaction scale is commonly used and reliable (i.e., internal consistency $\alpha$ at 0.80 or above) fiveitem version [6].

The response was recorded on a five-point scale wherein "1" indicates "strongly disagree" and "5" indicates "strongly agree". Both scales were translated from English language to Arabic language, which is the official language for all potential participants, using a back-translation technique. In doing so, a professor at Albaha University translated the modified questionnaire into Arabic language and then another professor at the same university translated back to English language without references to the original English version. Both professors are fully bilingual. After that, the researcher went carefully over both versions and made revisions needed in order to ensure a complete and accurate meaning of the original text of the modified questionnaire. In addition to that, the researcher wanted to ensure that an appropriate level of formality for all potential participants can be achieved.

\section{Data Analysis}

Descriptive statistics were used to summarize data. Cornbach alpha analysis was used to determine the internal consistency of the scales via alpha coefficient. Pearson correlation analysis was applied to examine the relationship between job and life satisfaction. Moreover, hierarchical multiple regression analysis was used to examine the bidirectional effects. This helped determine how other variables influence the two types of satisfaction and to see whether the satisfaction variables were still significantly related while controlling for all other variables. All statistical analyses were conducted using SPSS for Windows (version 19.0, 2010, Chicago, IL). Statistical significance at $\mathrm{P} \leq 0.05$ was used for all tests.

\section{Results}

Table 1 indicates that 63 (41.2\%) respondents were male while 90 (58.8\%) respondents were female. The ages of respondents ranged from 18 to 61 years old; a majority of respondents (83.6\%) were aged between 18 and 39 years old. As for the income that measured in Saudi Riyal, the respondents' income was ranged from less than 
Table 1. Demographic and Socio-economic characteristics of participants $(\mathrm{N}=153)$.

\begin{tabular}{|c|c|c|c|}
\hline Variable & Category & $\mathrm{N}$ & $\%$ \\
\hline \multicolumn{4}{|l|}{ Age } \\
\hline & $18-28$ & 64 & 41.8 \\
\hline & $29-39$ & 64 & 41.8 \\
\hline & $40-50$ & 21 & 13.7 \\
\hline & $51-61$ & 4 & 2.6 \\
\hline \multicolumn{4}{|l|}{ Gender } \\
\hline & Male & 63 & 41.2 \\
\hline & Female & 90 & 58.8 \\
\hline \multicolumn{4}{|c|}{ Income (RS) } \\
\hline & Less than 4999 & 50 & 32.7 \\
\hline & 5000 - 9999 & 61 & 39.9 \\
\hline & $10,000-14,999$ & 35 & 22.9 \\
\hline & 15,000 - 19,999 & 7 & 4.6 \\
\hline \multicolumn{4}{|l|}{ Sector } \\
\hline & Public employee & 105 & 68.6 \\
\hline & Private employee & 48 & 31.4 \\
\hline \multicolumn{4}{|c|}{ Marital status } \\
\hline & Married & 102 & 66.7 \\
\hline & Single & 46 & 30.1 \\
\hline & Other & 5 & 3.3 \\
\hline \multicolumn{4}{|c|}{ Educational level } \\
\hline & Less than high school & 4 & 2.6 \\
\hline & High school & 13 & 8.5 \\
\hline & Diploma & 7 & 4.6 \\
\hline & Bachelor or above & 129 & 84.3 \\
\hline
\end{tabular}

4999 to 19,999; a majority of respondents' income ranged from less than 4999 to 14,999, with a total rate of 72.6\%. Respondents worked in public organizations were 105 (68.6\%), whereas 48 (31.4\%) respondents were in private organizations. Of respondents, 102 (66.79\%) were married and 46 (30.1\%) were single. Finally, respondents who had bachelor degree or above presented the majority of the sample (129), showing a total rate of 84.3\%.

The Cronbach alpha of internal consistency was calculated in order to demonstrate the reliability of the survey's scale, namely job and life satisfaction scales. The analysis indicated that reliability test for job satisfaction scale ranged from 060 to 0.76 . As for life satisfaction scale, the analysis indicated that reliability test ranged from 0.56 to 0.68 . The summed scale showed a 0.69 and 0.65 coefficient alpha, respectively. Hence, the internal consistency for both questionnaires deemed substantially reliable [5].

To examine the correlation between job and life satisfaction, Pearson correlation analysis was carried out. As shown in Table 2, there was a statistically significant positive relationship between job and life satisfaction ( $\mathrm{r}=$ $0.35 ; \mathrm{P}=0.000)$. The strength of the relationship considered moderate [33]. The correlation is in the range $(0.31$ to 0.44$)$ reported in the literature [2] [34]. 
Table 2. Mean, stranded deviation, and correlation between job and life satisfaction $(\mathrm{N}=153)$.

\begin{tabular}{ccccc}
\hline Variables & Mean & SD & 1 & 2 \\
\hline 1. Job satisfaction & 3.51 & 0.55 & & $0.35^{* *}$ \\
2. Life satisfaction & 3.33 & 0.64 & $0.35^{* *}$ & \\
\hline
\end{tabular}

${ }^{* *}$ Correlation is significant at the 0.01 level (1-tailed).

The study research questions were addressed using hierarchical regression models (see Table 3 and Table 4). First, the study variables were regressed on life satisfaction through entering demographic variables (i.e., age, gender, and marital status), then socioeconomic variables (i.e., income, sector, and educational level), and, finally, job satisfaction. These equation models were repeated, using job satisfaction as the dependent variable, the entering the predictors just described, followed by life satisfaction. Hence, each type of satisfaction served as a dependent and independent variable in order to assess the bidirectional effects. This enabled to determine how the other variables influence the two types of satisfaction and to see whether the satisfaction variables were still significantly associated when controlling for all other variables.

The first study question considered job and life satisfaction relationship while controlling for demographic and socioeconomic variables. Having looked at Table 3 and Table 4, results indicated support for the first study question. There was a statistically significant relationship between job and life satisfaction $(\beta=0.33, \mathrm{P}<0.01)$, accounting for an incremental variance of $10 \%$ (F for change $=17.4, \mathrm{P}<0.01$ ), over and above the influence of all other variables (Table 3, Model 3). In the same vein, as shown in Table 4, there a statistically significant relationship between life and job satisfaction $(\beta=0.32, \mathrm{P}<0.01)$, for the second time, accounting for an incremental variance of $9 \%$ ( $\mathrm{F}$ for change $=17.4, \mathrm{P}<0.01)$.

The second study question investigated the pertinent contribution of the other predictor variables (Table 3 and Table 4) on life and job satisfaction. Going over to the $\mathrm{R}^{2}$ change values showed that in Model 1 , age variable made the strongest contribution to predicting job satisfaction ( $7 \%$ of the variance, Table 4$)$. The age variable ( $\beta$ $=0.22, \mathrm{P}<0.01$ ) uniquely predicted job satisfaction (Table 4, Model 3).

Because this study showed that age variable $(\beta=0.22, \mathrm{P}<0.01)$ uniquely predicted job satisfaction, further examination was carried out, using analysis of variance (ANOVA), followed by Tukey's post hoc test. As shown in (Table 5), there was a statistically significant difference between age and job satisfaction $(\mathrm{P}=0.009)$.

Tukey's post hoc test (Table 6) revealed that participants whose age ranged from 40 to 50 were more satisfied with their job $(\mathrm{M}=3.73$; $\mathrm{SD}=0.35)$ than those from 18 to 28 and from 29 to 39. Participates ranged in age from 29 to 39 were more satisfied with their job $(\mathrm{M}=3.61$; SD = 0.48) than those in age ranged from 18 to 28 .

\section{Discussion}

Because this study is the first of its kind in Southern Saudi Arabia, it paves the way for interested researchers to further examine the relationship between job and life satisfaction. The first study question addressed the relationship between job and life satisfaction while controlling for the influence of demographic and socioeconomic variables. Pearson correlation analysis showed a statistically significant positive relationship between job and life satisfaction. Hierarchical regression analysis confirmed that relationship, even after controlling for other variables. This finding lends support to the spillover model [3] [4] [16], and it is in parallel to preceding studies on job and life satisfaction relationships. Participants who reported being satisfied with their job would report being satisfied with their life and vice versa [3] [4] [16] [18]-[22].

Moreover, the result of hierarchical regression analysis proposed that there was a bidirectional correlation between job and life satisfaction. That is, job satisfaction significantly influenced life satisfaction, and life satisfaction significantly influenced life satisfaction. The influence of job satisfaction on life satisfaction $(\beta=0.33$, $\mathrm{P}$ $<0.01)$ was slightly and significantly stronger than the influence of life satisfaction on job satisfaction $(\beta=0.32$, $\mathrm{P}<0.01)$. This implied that job satisfaction is the central aspect of life satisfaction and life satisfaction is the central aspect of job satisfaction. Job can contribute to life satisfaction by providing income, a sense of identity, and a network of supportive relationships, to name a few. Life, on the other hand, can contribute to job satisfaction by providing strong family support, emotional stability, and social intelligence, to name a few [6] [35].

Age variable $(\beta=0.22, \mathrm{P}<0.01)$ uniquely predicted job satisfaction. Participants whose age ranged from 40 to 50 were more satisfied with their job $(\mathrm{M}=3.73$; $\mathrm{SD}=0.35)$ than those from 18 to 28 and from 29 to 39 . Par- 
Table 3. Hierarchical regressions results predicting life satisfaction $(\mathrm{N}=153)$.

\begin{tabular}{|c|c|c|c|c|c|c|c|c|c|}
\hline & \multicolumn{3}{|c|}{ Model 1} & \multicolumn{3}{|c|}{ Model 2} & \multicolumn{3}{|c|}{ Model 3} \\
\hline & B & SEB & $\beta$ & B & SEB & $\beta$ & B & SEB & $\beta$ \\
\hline Age in years & 0.13 & 0.08 & 0.16 & 0.10 & 0.08 & 0.12 & 0.03 & 0.08 & 0.04 \\
\hline Gender & 0.15 & 0.11 & 0.11 & 0.19 & 0.12 & 0.14 & 0.15 & 0.12 & 0.12 \\
\hline Marital status & 0.06 & 0.11 & 0.05 & 0.06 & 0.12 & 0.02 & 0.07 & 0.11 & 0.06 \\
\hline Income (SR) & & & & 0.07 & 0.09 & 0.09 & 0.04 & 0.09 & 0.05 \\
\hline Sector & & & & 0.10 & 0.17 & 0.07 & 0.08 & 0.16 & 0.05 \\
\hline Educational L. & & & & -0.10 & 0.08 & -0.12 & -0.11 & 0.08 & -0.12 \\
\hline Job satisfaction & & & & & & & 0.39 & 0.09 & $0.33^{* *}$ \\
\hline $\mathrm{R}^{2}$ & & & 0.03 & & & 0.05 & & & 0.15 \\
\hline $\mathrm{R}^{2}$ Change & & & 0.03 & & & 0.01 & & & 0.10 \\
\hline F Change in $\mathrm{R}^{2}$ & & & 1.7 & & & 0.66 & & & $17.4^{* * *}$ \\
\hline
\end{tabular}

${ }^{* * *} \mathrm{P}<0.01$

Table 4. Hierarchical regressions results predicting job satisfaction $(\mathrm{N}=153)$.

\begin{tabular}{|c|c|c|c|c|c|c|c|c|c|}
\hline & \multicolumn{3}{|c|}{ Model 1} & \multicolumn{3}{|c|}{ Model 2} & \multicolumn{3}{|c|}{ Model 3} \\
\hline & B & SEB & $\beta$ & B & SEB & $\beta$ & B & SEB & $\beta$ \\
\hline Age in years & 0.20 & 0.07 & $0.29^{* *}$ & 0.18 & 0.07 & 0.26 & 0.16 & 0.07 & $0.22^{* *}$ \\
\hline Gender & 0.12 & 0.09 & 0.11 & 0.08 & 0.10 & 0.08 & 0.03 & 0.09 & 0.03 \\
\hline Marital status & 0.00 & 0.09 & 0.00 & -0.20 & 0.09 & -0.02 & -0.04 & 0.09 & -0.04 \\
\hline Income (SR) & & & & 0.09 & 0.08 & 0.14 & 0.07 & 0.08 & 0.11 \\
\hline Sector & & & & 0.07 & 0.14 & 0.03 & 0.04 & 0.14 & 0.03 \\
\hline Educational L. & & & & 0.02 & 0.07 & 0.03 & 0.05 & 0.06 & 0.07 \\
\hline Life satisfaction & & & & & & & 0.28 & 0.07 & $0.32^{* * *}$ \\
\hline $\mathrm{R}^{2}$ & & & .07 & & & 0.08 & & & 0.18 \\
\hline $\mathrm{R}^{2}$ Change & & & .07 & & & 0.01 & & & 0.09 \\
\hline F Change in $\mathrm{R}^{2}$ & & & $3.8^{* * *}$ & & & 0.56 & & & $17.4^{* * *}$ \\
\hline
\end{tabular}

${ }^{* *} \mathrm{P}<0.01$.

Table 5. ANOVA results showing differences between age and job satisfaction ( $\mathrm{N}=153)$.

\begin{tabular}{cccccc}
\hline & Sum of Sq. & DF & Mean Sq. & F & Sig. \\
\hline Between groups & 3.43 & 3 & 1.14 & 3.98 & $0.009^{* *}$ \\
Within groups & 42.8 & 149 & 0.29 & & \\
Total & 46.3 & 152 & & & \\
\hline
\end{tabular}

${ }^{* *} \mathrm{P}<0.01$ 
Table 6. Post hoc Tukey HSD results showing multiple comparisons ( $\mathrm{N}=153)$.

\begin{tabular}{|c|c|c|c|c|c|}
\hline (I) Age (year) & (J) Age (year) & Mean & $\mathrm{SD}$ & Mean Diff. (I-J) & Sig. \\
\hline \multirow[t]{3}{*}{$18-28$} & $29-39$ & 3.34 & 0.64 & $-0.27^{*}$ & 0.03 \\
\hline & $40-50$ & & & $-0.38^{*}$ & 0.03 \\
\hline & $51-61$ & & & -0.28 & 0.74 \\
\hline \multirow[t]{3}{*}{$29-39$} & $18-28$ & 3.61 & 0.48 & $0.27^{*}$ & 0.03 \\
\hline & $40-50$ & & & -0.12 & 0.82 \\
\hline & $51-61$ & & & -0.02 & 1.0 \\
\hline \multirow[t]{3}{*}{$40-50$} & $18-28$ & 3.73 & 0.35 & $0.38^{*}$ & 0.03 \\
\hline & $29-39$ & & & 0.12 & 0.82 \\
\hline & $51-61$ & & & 0.10 & 0.99 \\
\hline \multirow[t]{3}{*}{$51-61$} & $18-28$ & 3.63 & 0.43 & 0.28 & 0.74 \\
\hline & $29-39$ & & & 0.02 & 1.0 \\
\hline & $40-50$ & & & -0.10 & 0.99 \\
\hline
\end{tabular}

*The mean difference is significant at the 0.05 level.

ticipates ranged in age from 29 to 39 were more satisfied with their job $(M=3.61$; $S D=0.48)$ than those in age ranged from 18 to 28 . That is, older participants were more satisfied with their job than younger participants. The relationship between age and job satisfaction was positive [36]-[38]. This positive relationship implied that employees were able to better adjust to their expectations to what job environment provides. The more time employees have been in a job, the more accurately they can predict and avoid frustration. It might imply that older employees basically earn more than younger employees, result in reporting a higher level of job satisfaction. Beside from that, employees are more likely to stay in jobs that provide them with high levels of autonomy and flexibility [39].

This study is not without limitations. First, the study sample is limited in that it was selected from one province in Southern Saudi Arabia, which has thirteen provinces. Hence, the results may not represent all these provinces. The second limitation regards generalizability of the findings when using a non-random sampling to collect the data. Finally, using a cross-sectional deign would not allow for confident casual conclusions associated with collecting all data concurrently.

\section{Conclusions}

The findings of this study indicate that spillover (positive relationship) is the predominant model of relationship between job and life satisfaction among employees, working in Albaha province, Saudi Arabia. It should be noted that the relationship between job and life satisfaction was statistically significant, even after controlling for demographic and socioeconomic variables. Some researchers regarded life satisfaction as extra-work variable and hence it should be excluded when examining the impact of some variables on organizational behavior. Nevertheless, findings of the current study claim that life satisfaction is rather related to behavior at work, including job satisfaction, which in turn, influences employees' mental and physical health and well-being.

The result also shows that the age variable was uniquely predicted job satisfaction. That is, new employees were less satisfied with their job than older employees. Accordingly, public and private organizations should pay more attention to newcomer adjustment during organizational socialization that is associated with important employee and organizational outcomes such as job satisfaction and performance.

\section{References}

[1] Eskildsen, J. and Dahlgaard, J. (2000) A Causal Model of Employee Satisfaction. Total Quality Management, 11, 10811094. http://dx.doi.org/10.1080/095441200440340 
[2] Ghiselli, R., La Lopa, J. and Bai, B. (2001) Job Satisfaction, Life Satisfaction, and Turnover Intent among Food-Service Managers. The Cornell Hotel and Restaurant Administration Quarterly, 42, 28-37.

[3] Mafini, C. (2014) The Relationship between Job Satisfaction and Life Satisfaction: Empirical Evidence from Logistics Practitioners in a South African Steel-Making Company. International Business \& Economics Research Journal, 13, 453-462.

[4] Heller, D., Judge, T. and Watson, D. (2002) The Confounding Role of Personality and Trait Affectivity in the Relationship between Job and Life Satisfaction. Journal of Organizational Behavior, 23, 815-835. http://dx.doi.org/10.1002/job.168

[5] Filiz, Z. (2014) An Analysis of the Levels of Job Satisfaction and Life Satisfaction of the Academic Staff. Social Indicators Research, 116, 793-808. http://dx.doi.org/10.1007/s11205-013-0319-6

[6] Judge T. and Klinger, R. (2008) Job Satisfaction: Subjective Well-Being at Work. In: Eid, M. and Larsen, R., Eds., The Science of Subjective Well-Being, Guilford Publications, New York, 393-413.

[7] Locke, E. (1978) The Motivation to Work: What We Know. Advances in Motivation and Achievement, 10, $375-412$.

[8] Diener, E., Emmons, R., Larsen, R. and Griffin, S. (1985) The Satisfaction with Life Scale. Journal of Personality Assessment, 49, 71-75. http://dx.doi.org/10.1207/s15327752jpa4901_13

[9] Shin D., and Johnson, D. (1978) Avowed Happiness as an Overall Assessment of the Quality of Life. Social Indicators Research, 5, 475-492. http://dx.doi.org/10.1007/BF00352944

[10] Diener, E. (1984) Subjective Well-Being. Psychological Bulletin, 95, 542-575. http://dx.doi.org/10.1037/0033-2909.95.3.542

[11] Tatarkiewicz, W. (1976) Analysis of Happiness. Nijhoff, Den Haag. http://dx.doi.org/10.1007/978-94-010-1380-2

[12] Brayfield, A., Wells, R. and Strate, M. (1957) Interrelationships among Measures of Job Satisfaction and General Satisfaction. Journal of Applied Psychology, 41, 201-205. http://dx.doi.org/10.1037/h0048095

[13] Judge, T. and Bono, J. (2001) Relationship of Core Self-Evaluations Traits—Self-Esteem, Generalized Self-Efficacy, Locus of Control, and Emotional Stability-With Job Satisfaction and Job Performance: A Meta-Analysis. Journal of Applied Psychology, 86, 80-92. http://dx.doi.org/10.1037/0021-9010.86.1.80

[14] Tait, M., Padgett, M. and Baldwin, T. (1989) Job and Life Satisfaction: A Reevaluation of the Strength of the Relationship and Gender Effects as a Function of the Date of the Study. Journal of Applied Psychology, 74, 502-507. http://dx.doi.org/10.1037/0021-9010.74.3.502

[15] Wilensky, H. (1960) Work, Careers and Social Integration. International Social Science Journal, 12, 543-560.

[16] Judge, T. and Watanabe, S. (1994) Individual Differences in the Nature of the Relationship between Job and Life Satisfaction. Journal of Occupational and Organizational Psychology, 67, 101-107. http://dx.doi.org/10.1111/j.2044-8325.1994.tb00554.x

[17] Brief, A., Butcher, A., George, J. and Link, K. (1993) Integrating Bottom-Up and Top-Down Theories of Subjective Well-Being: The Case of Health. Journal of Personality and Social Psychology, 64, 646-653. http://dx.doi.org/10.1037/0022-3514.64.4.646

[18] Ilies, R., Wilson, K. and Wagner, D. (2009) The Spillover of Daily Job Satisfaction onto Employees' Family Lives: The Facilitating Role of Work-Family Integration. Academy of Management Journal, 52, 87-102. http://dx.doi.org/10.5465/AMJ.2009.36461938

[19] Judge, T. and Watanabe, S. (1993) Another Look at the Job Satisfaction-Life Satisfaction Relationship. Journal of Applied Psychology, 78, 939-948. http://dx.doi.org/10.1037/0021-9010.78.6.939

[20] Georgellis, Y. and Lange, T. (2012) Traditional versus Secular Values and the Job-Life Satisfaction Relationship across Europe. British Journal of Management, 23, 437-454. http://dx.doi.org/10.1111/j.1467-8551.2011.00753.x

[21] Beutell, N. and Schneer, J. (2014) Job and Life Attitudes of Managers and Professionals. Journal of Psychological Issues in Organizational Culture, 4, 18-32. http://dx.doi.org/10.1002/jpoc.21123

[22] Dolan, S.L. and Gosselin, E. (1998) Job Satisfaction and Life Satisfaction: Analysis of a Reciprocal Model with Social Demographic Moderators. Working Paper, Ecole de relations industrielles, Universite de Montreal, Montreal.

[23] Loewe, N., Bagherzadeh, M., Araya-Castillo, L., Thieme, C. and Batista-Foguet, J. (2014) Life Domain Satisfactions as Predictors of Overall Life Satisfaction among Workers: Evidence from Chile. Social Indicators Research, 118, 7186. http://dx.doi.org/10.1007/s11205-013-0408-6

[24] Pavot, W. and Diener, E. (1993) Review of the Satisfaction with Life Scale. Psychological Assessment, 5, $164-172$. http://dx.doi.org/10.1037/1040-3590.5.2.164

[25] Pavot, W. and Diener, E. (2008) The Satisfaction with Life Scale and the Emerging Construct of Life Satisfaction. The Journal of Positive Psychology, 3, 137-152. http://dx.doi.org/10.1080/17439760701756946 
[26] Diener, E. (1994) Assessing Subjective Well-Being: Progress and Opportunities. Social Indicators Research, 31, 103157. http://dx.doi.org/10.1007/BF01207052

[27] Gadermann, A., Guhn, M. and Zumbo, B. (2012) Estimating Ordinal Reliability for Likert-Type and Ordinal Item Response Data: A Conceptual, Empirical, and Practical Guide. Practical Assessment, Research \& Evaluation, 17, 1-13.

[28] Oishi, S. (2006) The Concept of Life Satisfaction across Cultures: An IRT Analysis. Journal of Research in Personality, 40, 411-423. http://dx.doi.org/10.1016/j.jrp.2005.02.002

[29] Pons, D., Atienza, F., Balaguer, I. and Garcia-Merita, M. (2000) Satisfaction with Life Scale: Analysis of Factorial Invariance for Adolescents and Elderly Persons. Perceptual and Motor Skills, 91, 62-68. http://dx.doi.org/10.2466/pms.2000.91.1.62

[30] Durak, M., Senol-Durak, E. and Gencoz, T. (2010) Psychometric Properties of the Satisfaction with Life Scale among Turkish University Students, Correctional Officers, and Elderly Adults. Social Indicators Research, 99, 413-429. http://dx.doi.org/10.1007/s11205-010-9589-4

[31] Brayfield, A. and Rothe, H. (1951) An Index of Job Satisfaction. Journal of Applied Psychology, 35, 307-311. http://dx.doi.org/10.1037/h0055617

[32] Mak, B. and Sockel, H. (2001) A Confirmatory Factor Analysis of IS Employee Motivation and Retention. Information \& Management, 38, 265-276. http://dx.doi.org/10.1016/S0378-7206(00)00055-0

[33] Healey, J. (2009) The Essentials of Statistics: A Tool for Social Research. Wadsworth Cengage Learning, Belmont.

[34] Rode, J. (2004) Job Satisfaction and Life Satisfaction Revisited: A Longitudinal Test of an Integrated Model. Human Relations, 57, 1205-1230. http://dx.doi.org/10.1177/0018726704047143

[35] Rice, R., Near, J. and Hunt, R. (1980) The Job-Satisfaction/Life-Satisfaction Relationship: A Review of Empirical Research. Basic and Applied Social Psychology, 1, 37-64. http://dx.doi.org/10.1207/s15324834basp0101_4

[36] Hulin, C. and Smith, P. (1965) A Linear Model of Job Satisfaction. Journal of Applied Psychology, 49, 209-216. http://dx.doi.org/10.1037/h0022164

[37] Hunt, J. and Saul, P. (1975) The Relationship of Age, Tenure, and Job Satisfaction in Males and Females. Academy of Management Journal, 18, 690-702. http://dx.doi.org/10.2307/255372

[38] Ng, T. and Feldman, D. (2010) The Relationships of Age with Job Attitudes: A Meta-Analysis. Personnel Psychology, 63, 677-718. http://dx.doi.org/10.1111/j.1744-6570.2010.01184.x

[39] Perrewé, P., Rosen, C. and Halbesleben, J., Eds. (2014) The Role of Demographics in Occupational Stress and Well Being. Emerald Group Publishing, Bingley. 
Scientific Research Publishing (SCIRP) is one of the largest Open Access journal publishers. It is currently publishing more than 200 open access, online, peer-reviewed journals covering a wide range of academic disciplines. SCIRP serves the worldwide academic communities and contributes to the progress and application of science with its publication.

Other selected journals from SCIRP are listed as below. Submit your manuscript to us via either submit@scirp.org or Online Submission Portal.
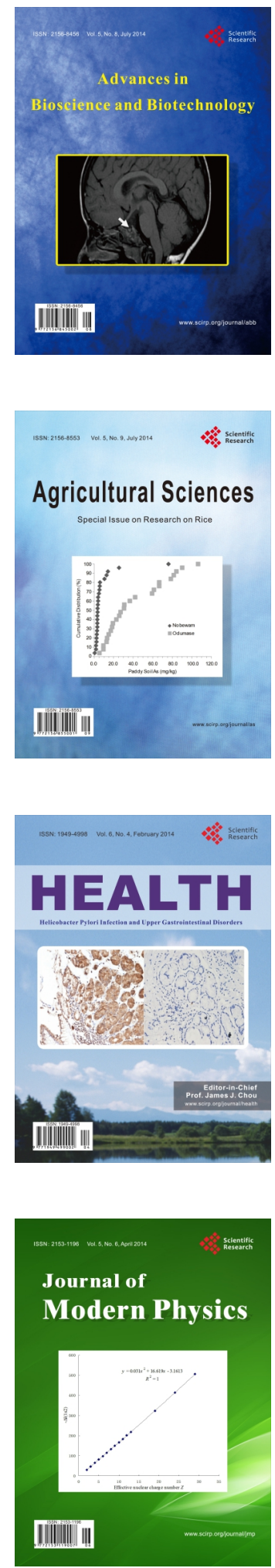
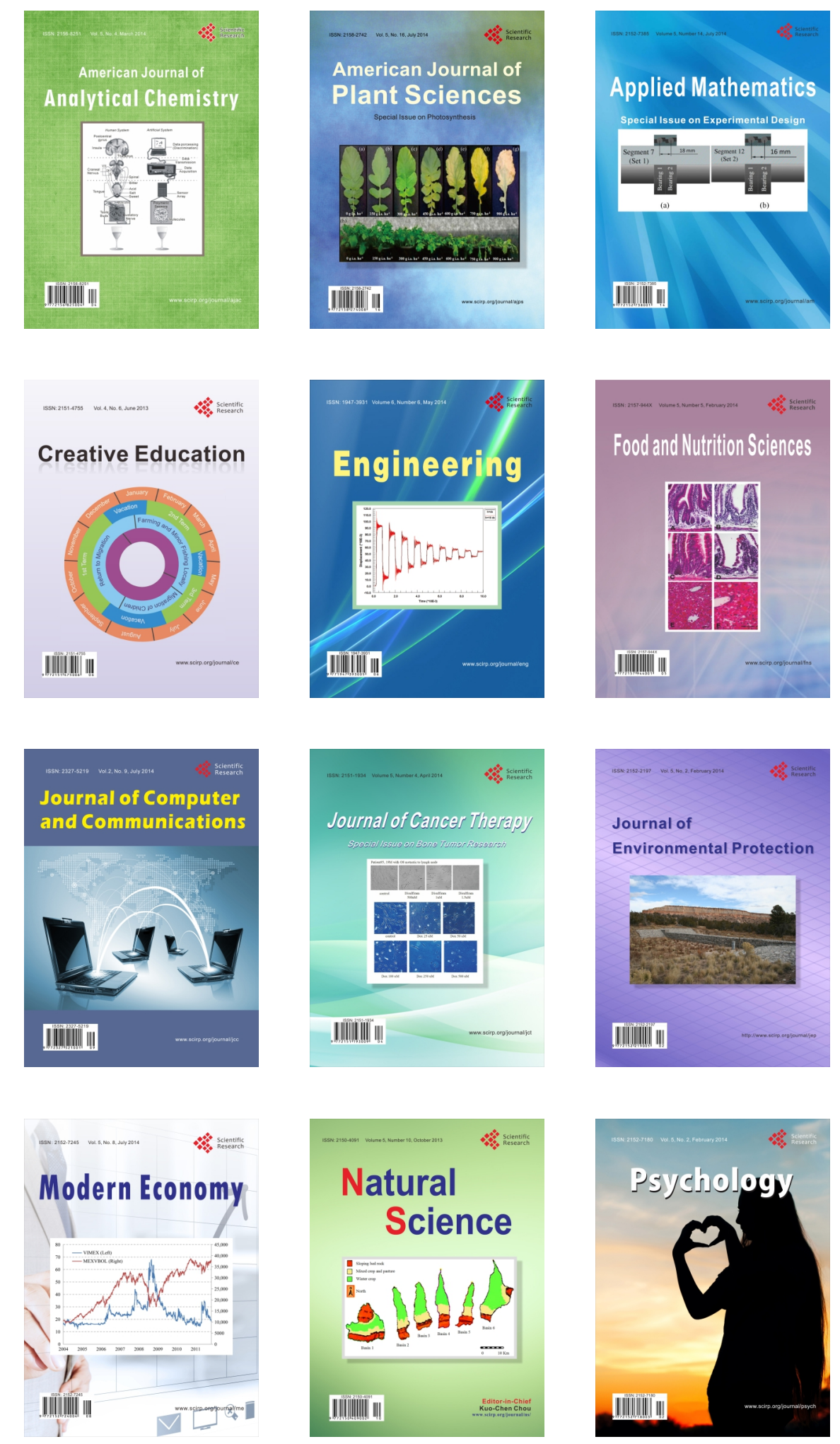